\title{
Potential Role of Propolis in the Prevention and Treatment of Metabolic Diseases
}

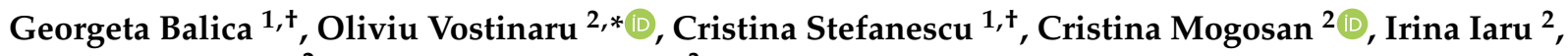 \\ Anamaria Cristina ${ }^{2}$ and Carmen Elena Pop ${ }^{3}$
}

1 Department of Pharmaceutical Botany, Iuliu Hatieganu University of Medicine and Pharmacy, 23 Gh. Marinescu Street, 400337 Cluj-Napoca, Romania; bgeorgeta@umfcluj.ro (G.B.); cstefanescu@umfcluj.ro (C.S.)

2 Department of Pharmacology, Physiology and Physiopathology, Iuliu Hatieganu University of Medicine and Pharmacy, 6 L. Pasteur Street, 400349 Cluj-Napoca, Romania; cmogosan@umfcluj.ro (C.M.); cazacuirina16@gmail.com (I.I.); cristina.anam@yahoo.com (A.C.)

3 Department of Pharmaceutical Industry, Iuliu Hatieganu University of Medicine and Pharmacy, 12 I. Creanga Street, 400010 Cluj-Napoca, Romania; carmen.pop@umfcluj.ro

* Correspondence: oliviu_vostinaru@yahoo.com

+ These authors contributed equally to this work.

Citation: Balica, G.; Vostinaru, O.; Stefanescu, C.; Mogosan, C.; Iaru, I.; Cristina, A.; Pop, C.E. Potential Role of Propolis in the Prevention and Treatment of Metabolic Diseases. Plants 2021, 10, 883. https://doi. org/10.3390/plants10050883

Academic Editor: Otilia Bobis

Received: 22 March 2021

Accepted: 23 April 2021

Published: 27 April 2021

Publisher's Note: MDPI stays neutral with regard to jurisdictional claims in published maps and institutional affiliations.

Copyright: (c) 2021 by the authors. Licensee MDPI, Basel, Switzerland. This article is an open access article distributed under the terms and conditions of the Creative Commons Attribution (CC BY) license (https:// creativecommons.org/licenses/by/ $4.0 /)$.

\begin{abstract}
Propolis is a resinous mixture with a complex chemical composition, produced by honeybees and stingless bees from a variety of vegetal sources. In the last decades, propolis was extensively researched, multiple studies confirming its anti-inflammatory, antioxidant, antimicrobial, and woundhealing properties. More recently, due to an exponential increase in the number of patients with metabolic diseases, there is also a growing interest in the study of antidiabetic, antihyperlipidemic, and anti-obesity effects of propolis. The aim of this review was to evaluate the potential role of propolis in the prevention and treatment of metabolic diseases like diabetes mellitus, dyslipidemia, and obesity. The preclinical in vivo and in vitro pharmacological models investigating antidiabetic, antihyperlipidemic, and anti-obesity effects of propolis were reviewed with a focus on the putative mechanisms of actions of several chemical constituents. Additionally, the available clinical studies and an evaluation of the safety profile of propolis were also presented.
\end{abstract}

Keywords: propolis; antidiabetic; antihyperlipidemic; anti-obesity

\section{Introduction}

Propolis, commonly known as the "bee glue", is a natural resinous mixture produced by honeybees (mostly Apis mellifera) and some other bees, such as stingless bees from resinous and gummy substances gathered from leaves, buds, sap flows, trichomes, and other actively exuding plant structures. Honeybees take the vegetable materials with their mandibles and mix them with some salivary enzymes like alpha-amylase, betaamylase, maltase, or some esterases. Other bees, such as stingless bees species produce propolis by collecting resinous material from plants and mixing it with beeswax and soil to form the so called geopropolis. Bees are using propolis to protect hives by blocking the cracks, sealing the spaces, and smoothing out the internal walls to maintain a constant inner temperature and to attain an internal aseptic environment [1-5].

Bee products have been used since ancient times as important bioresources because of their widely beneficial properties. Egyptians, Greeks, and Romans reported the biological properties of propolis for lesion healing. Aristotle, Dioscorides, Pliny, and Galen described some of the medicinal properties of propolis and they used propolis as antiseptic and mouth disinfectant as well as for healing wounds. In the medieval period, these applications of propolis were spread by Arabian physicians. The Incas used propolis as an antipyretic. Since the 18th century, propolis was first included in the London Pharmacopeia as an official drug. Between, the 17th and 20th centuries, propolis became popular in Europe, 
due to its antibacterial activity. During the Second World War, propolis was used as an antimicrobial and anti-inflammatory agent $[6,7]$.

The World Health Organization estimates that between $70 \%$ and $95 \%$ of the population from developing countries use natural products as a therapeutic alternative [6]. Nowadays, propolis is available in the form of capsules, as an extract, as a mouthwash, in throat lozenges, creams, and in powder form as well as part of cosmetic formulations and health food items [7]. The wide application of propolis in modern medicine is due to its diverse pharmacological and biological properties, such as antibacterial, antifungal, antiviral, antiprotozoal, antioxidative, spasmolytic, astringent, anti-inflammatory, anesthetic, antitumor, immunostimulant, and hepatoprotective properties [1-3,8].

Recently, due to an exponential increase in the number of patients with metabolic diseases which could lead to significant or even fatal cardiovascular complications, propolis was also tested in vivo and in vitro for antidiabetic, antihyperlipidemic, or anti-obesity effects, with promising results. The aim of this review was to present the preclinical, clinical, and safety data linked to the potential role of propolis in the prevention and treatment of metabolic diseases, highlighting also the available mechanistic studies on individual chemical constituents.

\section{Materials and Methods}

This study is a review of available scientific data concerning the effects of propolis in the prevention and treatment of metabolic diseases. A search was performed in Web of Science, PubMed, and Scopus scientific databases, including the last twenty years. The search terms "propolis", "antidiabetic" ("hypoglycemic"), "dyslipidemia" ("antihyperlipidemic"), and "obesity" were used for data selection. Only full-text articles in English were included in this work. Our study identified 54 preclinical and clinical studies, a total of 30 studies being selected after the removal of duplicates and materials written in other languages.

\section{Types of Propolis and Chemical Composition}

The botanical source of propolis is represented by several different plants distributed all over the world. Exudates from poplar buds (Populus spp.) are described as the main botanical source of propolis from temperate regions, as well as birch (Betula alba L.), horse chestnut (Aesculus hippocastanum L.), alder (Alnus glutinosa Medik), beech (Fagus sylvatica L.), and some conifers $[9,10]$. In propolis samples from different tropical regions, the main plant sources are Baccharis dracunculifolia D.C., Araucaria angustifolia (Bertol.) Kuntze, Clusia minor L., Clusia rosea Jacq., Dalbergia ecastophyllum (L.) Taub., Macaranga tanarius (L.) Müll. Arg., Hyptis divaricata Pohl. ex. Benth, and Eucalyptus citriodora (Hook) [10,11]. The most important bee products, such as honey and pollen are referred to the botanical name of the plant from which they originate [2]. Based on the plant source and the area of collection, propolis has been categorized into seven types: poplar, birch, Brazilian green, Brazilian red, Clusia, Pacific, and Mediterranean [12,13]. Propolis composition is extremely complex and variable, showing the presence of $50-55 \%$ resin, $30 \%$ beeswax, $10-15 \%$ essential oils, and $5 \%$ pollen $[3,14,15]$. Physical properties, such as color, aroma, and consistency of propolis depend on factors like geographic origin, types of vegetal sources, time of collection, and season of the year [1,2]. The color varies from yellow, green to red, and dark brown $[4,15]$. Propolis has a typical odor and a bitter taste [16]. The odor can vary from sample to sample, having a distinct flavor and an aromatic pleasant smell, some samples being odorless [15-17]. This complex mixture has variable consistency, it is hard and brittle when cold but becomes soft and very sticky when warm [16].

The chemical composition of propolis strongly depends on geographical location. Botanical origins and chemical composition of propolis have a close relationship leading to great variation in constituents of the propolis [18]. Extensive research was conducted over the years on different molecules identified in the composition of propolis and until 2018 more than 850 compounds were reported, 305 of them isolated for the first time between 2013 and 2018. As propolis samples from unexplored areas (mainly in Africa or Asia) 
are being analyzed, the number of constituents is constantly increasing, new compounds being reported in studies published between 2018 and 2021, such as new flavanones and phenantrendiol derivatives in African samples, and new prenylflavonoids in Asian samples [19-21].

Generally, a propolis sample contains in average 80-100 different constituents [4]. The specific compounds of the propolis are phenolic compounds (flavonoids as main constituents, phenolic acids, and their esters, phenylpropanoids), terpenes and terpenoids, ketones, aromatic aldehydes and alcohols, proteins, fatty acids, waxy acids, amino acids, hydrocarbons, steroids, stilbenes, sugars, vitamins, minerals, and enzymes. The phenolic compounds are believed to be the most representative biologically active constituents of propolis, especially in poplar type. They were found to represent on average around $28 \%( \pm 9 \%)$ of the whole mass of poplar propolis, among which $8 \%( \pm 4 \%)$ are flavones / flavonols and $6 \%( \pm 2 \%)$ are flavanones/dihydroflavonols [4]. Other compounds, such as the flavonoid glycosides, alkaloids, and tannins were discovered recently $[1,4,22]$. The main chemical compounds from propolis are presented in Table 1.

Table 1. Main chemical compounds present in the composition of honeybees and stingless bees propolis.

\begin{tabular}{|c|c|}
\hline Flavonoids & $\begin{array}{l}\text { apigenin, kaempferol, pinobanksin, chrysin, tektochrisin, pinocembrin, galangin, quercetin, } \\
\text { myricetin, rutin, rhamnetin, isorhamnetin, luteolin, naringenin, acacetin, baicalein, hesperitin, } \\
\text { sakuranetin, formononetin, liquiritigenin, isalpinin, daidzein, genistein, eupatorin, hispidulin, } \\
\text { propolins, prokinawan, isosativan, medicarpin, vestitol, nymphaeol, isonymphaeol [1,18,23-33] }\end{array}$ \\
\hline $\begin{array}{l}\text { Phenyl carboxylic acids and } \\
\text { derivatives }\end{array}$ & $\begin{array}{l}\text { caffeic acid, caffeic acid phenethyl ester, cichoric acid, cinnamic acid, ferulic acid, } p \text {-coumaric acid, } \\
\text { benzoic acid, salicylic acid, rosmarinic acid, chlorogenic acid, caffeoylquinic acid, vanillic acid, } \\
\text { artepillin } C \text {, baccharin, drupanin }[18,22,27,29,33-38]\end{array}$ \\
\hline Terpenoids & $\begin{array}{l}\text { geraniol, nerol, bisabolol, guaiol, farnesol, linalool, limonene, eudesmol, terpineol, camphor, } \\
\text { squalene, copaene, calarene, calamenene, caryophyllene, patchoulene, elemene, ferruginol, } \\
\text { junicedric acid, pimaric acid, abietic acid, isocupressic acid, acetylisocupressic acid, communic } \\
\text { acid, imbricatoloic acid, totarol, amyrin, amyrone, lupeol, lupenone, moretenol, ferutinin, teferin, } \\
\text { germanicol, agarospirol, lanosterol, erythrodiol, cycloartenol, ambonic acid, mangiferonic acid, } \\
\text { ambolic acid }[1,6,22,28,31,34,35,37,39-44]\end{array}$ \\
\hline Amino acids & $\begin{array}{l}\text { aspartic acid, glutamic acid, serine, glycine, histidine, arginine, threonine, alanine, proline, } \\
\text { tyrosine, valine, methionine, isoleucine, leucine, phenylalanine, lysine, tryptophane, asparagine, } \\
\text { cystine }[1,45]\end{array}$ \\
\hline $\begin{array}{l}\text { Aliphatic hydrocarbons and } \\
\text { aliphatic acids }\end{array}$ & $\begin{array}{l}\text { eicosine, 1-octadecene, eicosane, heneicosane, docosane, tricosane, tetracosane, pentacosane, } \\
\text { hexacosane, heptacosane, octacosane, nonacosane, triacontane, behenic acid, cerotic acid, lauric } \\
\text { acid, linoleic acid, lignoceric acid, montanic acid, nonanoic acid, palmitic acid, oleic acid, stearic } \\
\text { acid, behenic acid, decanoic acid, dodecanoic acid, tetradecanoic acid, heptadecanoic acid, } \\
\text { tetracosanoic acid, eicosanoic acid, hexacosanoic acid }[1,34,43,46]\end{array}$ \\
\hline Sugars and sugar alcohols & $\begin{array}{l}\text { xylose, galactose, mannose, glucuronic acid, lactose, maltose, melibiose, d-ribofuranose, } \\
\text { d-fructose, d-gulose, talose, sucrose, d-glucose, erytritol, xylitol, inositol, d-glucitol }[1,33]\end{array}$ \\
\hline Vitamins & B1, B2, B3, B5, B6, C, E $[1,4,45]$ \\
\hline Minerals & Sr, Ba, Cd, Sn, Pb, Ti, Ag, Co, Mo, Al, Si, V, Ni, Mn, Cr, Na, Mg, Cu, Ca, Zn, Fe, K [1,33] \\
\hline Alkaloids & demecolcine, papaverine, thebaine, morpholine, norlobeline, pagicerine, oreophilin $[4,34,44]$ \\
\hline
\end{tabular}

For each of the seven types of propolis, several compounds are specific, although the phenolic compounds (flavonoids, aromatic acids, and their esters) are characteristic for the propolis obtained from temperate regions (Europe, Asia, North America) and terpenoids for that obtained from tropical (Brazil, Africa) and Mediterranean regions [35,37,41-43].

Poplar propolis is produced in temperate zones and the main botanical sources are the bud exudates of Populus species, mostly Populus nigra L. [4,9,42,47]. It is composed mainly of flavonoids (chrysin, galangin, pinocembrin, pinobanksin, pinobanksin-3-Oacetate, pinocembrin chalcone, quercetin, kaempferol, apigenin, naringenin), phenolic acids, and their esters, sesquiterpenes [36,37,48-52]. 
Birch propolis is produced in Russia from birch buds and it consists mainly of flavones, flavonols, flavonones, and sesquiterpenes [1,4,47,48].

Brazil green propolis, the most popular tropical propolis type, is originate from the leaves of Baccharis dracunculifolia D.C. Recently, Brazil red propolis that originates from red resinous exudates at the surface and the branch orifice of Dalbergia ecastophyllum (L.) Taub $[4,43]$ was discovered. Green and red propolis are the most common of the 13 types of Brazilian propolis and are composed of prenylated phenylpropanoids (specifically artepillin C, baccharin, drupanin in green propolis), phenolic acids, p-coumaric acids, diterpenic acids, kaempferide, apigenin, isosakuranetin, and typically for red propolis, formononetin, isoliquiritigenin, biochanin A, daidzein, vestitol [21,26,33,34,44,48].

Another tropical propolis type, Clusia propolis or Cuban red propolis is the one originating from resin exuded by the flowers of different Clusia species found in Cuba and Venezuela $[4,52]$. It is rich in isoflavones, isoflavanes, flavonoids, and isoprenylated benzophenones [31,47].

Pacific propolis or Taiwanese green propolis found in Taiwan, Okinawa, and Indonesia originates from the fruits of Macaranga tanarius (L.) Müll. Arg. [4,53]. This type of propolis is characterized by the presence of prenylated flavonoids (propolins, prokinawan, nymphaeol, isonymphaeol) $[33,47,53]$.

The specificity of Mediterranean propolis, that seems to originate from cypress, is the high concentration of terpenoids (mainly totarol and diterpenic acids: isocupressic, communic, pimaric, imbricatoloic, abietic acids). This type is found in Greece, Malta, Sicily, Turkey, and Algeria [4,28,37,42,47,52]. If this propolis is obtained solely of cypress trees, the extract does not contain flavonoids, nor phenolic acids, but only diterpenes totarol and totarolon at high concentrations [50].

In the last decades, propolis has gained extensive popularity as a functional food and dietary supplement. In order to extract propolis for commercial purposes, ethanol, glycerol, and water are the main solvents employed, other solvents being also available. Ethanol is currently the most used solvent to obtain low wax propolis extracts rich in biologically active compounds. Recently, new methods of extracting propolis have been studied in order to replace the conventional ethanolic extraction method. One of the most promising methods is supercritical fluid extraction, which has the capacity to retain the antioxidant properties of the obtained propolis extracts through its use of low temperatures, which is an important characteristic for the pharmaceutical and food industries [54].

\section{Preclinical Studies Investigating the Effects of Propolis in Metabolic Diseases}

Our review identified 22 preclinical in vivo and in vitro studies, which were focused on the investigation of the effects of propolis in metabolic diseases like diabetes mellitus, dyslipidemia, or obesity (Table 2). 
Table 2. Preclinical studies (in vivo and in vitro) investigating the effect of propolis in metabolic diseases.

\begin{tabular}{|c|c|c|c|}
\hline No. & Experimental Model/Dose of Propolis (In Vivo) & Findings & Reference \\
\hline \multicolumn{4}{|c|}{ Antidiabetic effect } \\
\hline 1. & D-glucose induced diabetes in rats $/ 100-200 \mathrm{mg} / \mathrm{kg}$ & $\begin{array}{l}\text { Reduction of fasting blood glucose; reduction of } \\
\text { insulin resistance; reduction of body weight }\end{array}$ & $\begin{array}{l}\text { Laaroussi et al., } 2020 \\
\text { [55] }\end{array}$ \\
\hline 2. & Streptozotocin induced diabetes in rats $/ 300 \mathrm{mg} / \mathrm{kg}$ & Reduction of fasting blood glucose & Nna et al., 2019 [56] \\
\hline 3. & Streptozotocin induced diabetes in rats $/ 50-100 \mathrm{mg} / \mathrm{kg}$ & $\begin{array}{l}\text { Reduction of blood glucose; reduction of serum } \\
\text { creatinine and urea }\end{array}$ & $\begin{array}{l}\text { El Menyiy et al., } 2019 \\
\text { [57] }\end{array}$ \\
\hline 4. & Streptozotocin induced diabetes in mice $/ 300 \mathrm{mg} / \mathrm{kg}$ & Reduction of blood glucose & $\begin{array}{l}\text { Rivera-Yanez et al., } \\
2018 \text { [58] }\end{array}$ \\
\hline 5. & In vitro assessment of alpha-glucosidase & $\begin{array}{l}\text { Inhibition of alpha-glucosidase with IC50 of } 70.79 \\
\qquad \pm 6.44 \mu \mathrm{g} / \mathrm{mL}\end{array}$ & Vongsak et al., 2015 [59] \\
\hline 6. & In vitro assessment of alpha-glucosidase and $\alpha$-amylase & $\begin{array}{c}\text { Inhibition of alpha-glucosidase with IC50 of } 0.01 \pm \\
0.01 \mathrm{mg} / \mathrm{mL} \text {; inhibition of alpha-amylase with } \\
\text { IC50 of } 0.09 \pm 0.01 \mathrm{mg} / \mathrm{mL}\end{array}$ & Popova et al., 2015 [60] \\
\hline 7. & Alloxan induced diabetes in rats $/ 200-300 \mathrm{mg} / \mathrm{kg}$ EO & $\begin{array}{l}\text { Reduction of blood glucose; conservation of } \\
\text { normal pancreatic cell architecture }\end{array}$ & $\begin{array}{l}\text { Babatunde et al., } 2015 \\
\text { [61] }\end{array}$ \\
\hline 8. & Streptozotocin induced diabetes in rats $/ 100 \mathrm{mg} / \mathrm{kg}$ & $\begin{array}{l}\text { Reduction of fasting blood glucose; reduction of } \\
\text { glycated hemoglobin; restoration of STZ-altered } \\
\text { hepatorenal functions }\end{array}$ & Zhu et al., 2013 [62] \\
\hline 9. & Streptozotocin induced diabetes in rats $/ 200 \mathrm{mg} / \mathrm{kg}$ & $\begin{array}{l}\text { Reduction of serum glucose; reduction of oxidative } \\
\text { stress parameters }\end{array}$ & El Sayed et al., 2009 [63] \\
\hline 10. & Fructose induced diabetes in rats $/ 100-300 \mathrm{mg} / \mathrm{kg}$ & $\begin{array}{l}\text { Reduction of plasma level of insulin and HOMA-R } \\
\text { index of insulin resistance }\end{array}$ & Zamami et al., 2007 [64] \\
\hline 11. & Alloxan induced diabetes in rats $/ 1 \mathrm{~mL} / 100 \mathrm{~g}$ & $\begin{array}{l}\text { Reduction of blood glucose; reduction of } \\
\text { fructosamine, malonaldehyde and nitric oxide }\end{array}$ & Fuliang et al., 2005 [65] \\
\hline 12. & In vitro assessment of maltase and $\alpha$-amylase & $\begin{array}{c}\text { Inhibition of maltase with IC50 of } 1.0 \mathrm{mg} / \mathrm{mL} \text {; } \\
\text { inhibition of alpha-amylase with IC50 of } 4.7 \\
\mathrm{mg} / \mathrm{mL}\end{array}$ & Matsui et al., 2004 [66] \\
\hline \multicolumn{4}{|c|}{ Antihyperlipidemic effect } \\
\hline 13. & High-fat diet mice $/ 50 \mathrm{mg} / \mathrm{kg}$ & $\begin{array}{l}\text { Reduction of total cholesterol and triglycerides; } \\
\text { reduction of atherogenic index of plasma }\end{array}$ & Orsolic et al., 2019 [67] \\
\hline 14. & $\begin{array}{l}\text { Sodium nitrite induced hyperlipidemia in guinea pigs/200 } \\
\qquad \mathrm{mg} / \mathrm{kg}\end{array}$ & $\begin{array}{l}\text { Reduction of cholesterol, triglycerides; reduction } \\
\text { of atherogenic index of plasma }\end{array}$ & Azab et al., 2015 [68] \\
\hline 15. & High-fat diet rats $/ 1-2 \% w / w$ & Reduction of cholesterol, triacylgycerol and ALT & Albokhadaim, 2015 [69] \\
\hline 16. & LDL $\mathrm{r}-/-$ mice $/ 70 \mu \mathrm{L} /$ animal & $\begin{array}{l}\text { Increase of plasmatic HDL; prevention of LVH and } \\
\text { arterial atherogenesis }\end{array}$ & Silva et al., 2015 [70] \\
\hline 17. & ApoE-knockout mice $/ 160 \mathrm{mg} / \mathrm{kg}$ & $\begin{array}{l}\text { Reduction of total cholesterol, triglycerides, } \\
\text { and non-HDL; decrease atherosclerotic lesion } \\
\text { development in aortic root }\end{array}$ & Fang et al., 2013 [71] \\
\hline 18. & LDL r-/- mice/250 mg/kg & $\begin{array}{l}\text { Normalisation of lipid profile/downregulation of } \\
\text { VCAM, FGF, VEGF and MMP-9 gene expression }\end{array}$ & $\begin{array}{l}\text { Daleprane et al., } 2012 \\
{[72]}\end{array}$ \\
\hline 19. & High-fat diet rabbits $/ 75 \mathrm{mg} / \mathrm{kg}$ & $\begin{array}{c}\text { Reduction of total cholesterol, LDL and } \\
\text { triglycerides }\end{array}$ & Nader et al., 2010 [73] \\
\hline 20. & High-fat diet rats $/ 0.05-0.5 \% w / w$ & $\begin{array}{l}\text { Reduction of cholesterol and triglycerides/increase } \\
\text { of PPAR } \alpha \text { protein level in the liver }\end{array}$ & Ichi et al., 2009 [74] \\
\hline \multicolumn{4}{|c|}{ Anti-obesity effect } \\
\hline 21. & Obese C57BL/6J mice & $\begin{array}{l}\text { Increased thermogenesis in white adipose tissue } \\
\text { (WAT); activation of creatine metabolism pathways }\end{array}$ & $\begin{array}{l}\text { Nishikawa et al., } 2020 \\
\text { [75] }\end{array}$ \\
\hline 22. & Obese C57BL/6J mice/5-50 mg/kg & $\begin{array}{c}\text { Reduction of body weight gain; down-regulation } \\
\text { of fatty acid synthase and SREBP mRNA } \\
\text { expression }\end{array}$ & $\begin{array}{l}\text { Koya-Miyata et al., } \\
2009 \text { [76] }\end{array}$ \\
\hline
\end{tabular}

The in vivo animal models used to evaluate antidiabetic effect of propolis used streptozotocin (STZ), alloxan, D-glucose, or fructose to induce specific pathological modifications in glucose metabolism leading to chronic hyperglycemia, a key factor associated with 
cardiovascular complications. In these studies, the administration of propolis reduced the rise of blood glucose and ameliorated insulinemia with protective effects on pancreatic beta cells in chemically induced diabetes mellitus [55-58]. Additionally, several in vitro studies demonstrated inhibitory effects of propolis on several enzymes involved in glucose metabolism (alpha-glucosidase, maltase, or alpha-amylase), with the reduction of digestive absorption of glucose, which may also contribute to the overall antidiabetic effect $[59,60,66]$.

For the evaluation of the effects of propolis in dyslipidemia, the majority of the in vivo experimental models used a high-fat diet in order to induce an increase in the serum concentration of cholesterol and triglycerides and only one model used sodium nitrate to induce hypercholesterolemia [68]. Another experimental approach was to use genetically engineered animals like APOE2 or LDL r-/- transgenic mice, which develop severe dyslipidemia due to alterations of enzymes and receptors involved in cholesterol metabolism [70-72]. In all experiments, the administration of propolis decreased the concentration of total cholesterol, LDL, and triglycerides. Additionally, propolis proved to be protective against the development of aortic lesions and arterial atherogenesis in transgenic animals [71].

The experimental models used to study the anti-obesity effect of propolis used C57BL/6J mice, in which the weight gain was diet induced. The treatment with propolis caused a reduction of body weight gain and an increased thermogenesis in adipose tissue, also reducing the accumulation of visceral adipose tissue $[75,76]$.

\section{Clinical Studies Investigating the Effects of Propolis in Metabolic Diseases}

The effects of propolis in metabolic diseases were investigated in eight clinical studies focused on diabetes, obesity, or diabetic complications like diabetic foot ulcer (Table 3).

Table 3. Clinical studies with propolis administered in metabolic diseases.

\begin{tabular}{|c|c|c|c|c|c|}
\hline Disease & Type of Clinical Study & Number of Patients & Treatment/Dose & Results & Reference \\
\hline $\begin{array}{l}\text { Diabetes } \\
\text { mellitus }\end{array}$ & $\begin{array}{c}\text { Randomized, } \\
\text { placebo-controlled study }\end{array}$ & $\begin{array}{c}62 \text { patients with type } 2 \\
\text { diabetes }\end{array}$ & $\begin{array}{c}1500 \mathrm{mg} / \text { day } \\
\text { propolis, orally for } 8 \\
\text { weeks }\end{array}$ & $\begin{array}{c}\text { Reduction of } \mathrm{HbA} 1 \mathrm{C} ; \\
\text { increase of TAC blood } \\
\text { levels and activity of GPx } \\
\text { and SOD }\end{array}$ & $\begin{array}{c}\text { Afsharpour } \\
\text { et al., } 2019 \text { [77] }\end{array}$ \\
\hline $\begin{array}{l}\text { Diabetes } \\
\text { mellitus }\end{array}$ & $\begin{array}{l}\text { Randomized, } \\
\text { placebo-controlled study }\end{array}$ & $\begin{array}{c}50 \text { patients with type } 2 \\
\text { diabetes }\end{array}$ & $\begin{array}{c}1000 \mathrm{mg} / \text { day } \\
\text { propolis, orally for } 90 \\
\text { days }\end{array}$ & $\begin{array}{l}\text { Reduction of HbA1C, } \\
\text { HOMA-IR, hs-CRP }\end{array}$ & $\begin{array}{l}\text { Zakerkish et al., } \\
2019 \text { [78] }\end{array}$ \\
\hline $\begin{array}{l}\text { Diabetes } \\
\text { mellitus }\end{array}$ & $\begin{array}{l}\text { Randomized, } \\
\text { placebo-controlled study }\end{array}$ & $\begin{array}{c}66 \text { patients with type } 2 \\
\text { diabetes }\end{array}$ & $\begin{array}{l}900 \mathrm{mg} \text { /day propolis, } \\
\text { orally for } 12 \text { weeks }\end{array}$ & $\begin{array}{l}\text { Significant reduction of } \\
\text { FBG and } \mathrm{HbA} 1 \mathrm{C} \text {; decrease } \\
\text { of total cholesterol }\end{array}$ & $\begin{array}{l}\text { Samadi et al., } \\
2017 \text { [79] }\end{array}$ \\
\hline $\begin{array}{l}\text { Diabetes } \\
\text { mellitus }\end{array}$ & $\begin{array}{l}\text { Randomized controlled } \\
\text { study }\end{array}$ & $\begin{array}{c}32 \text { patients with type } 2 \\
\text { diabetes }\end{array}$ & $\begin{array}{l}900 \mathrm{mg} \text { /day propolis, } \\
\text { orally for } 18 \text { weeks }\end{array}$ & $\begin{array}{l}\text { Reduction of carbonyls, } \\
\text { LDH activity and TNF } \alpha\end{array}$ & $\begin{array}{c}\text { Zhao et al., } 2016 \\
\text { [80] }\end{array}$ \\
\hline $\begin{array}{l}\text { Diabetes } \\
\text { mellitus }\end{array}$ & $\begin{array}{l}\text { Randomized, } \\
\text { placebo-controlled study }\end{array}$ & $\begin{array}{c}80 \text { patients with type } 2 \\
\text { diabetes }\end{array}$ & $\begin{array}{l}226.8 \mathrm{mg} / \text { day } \\
\text { propolis, orally for } 8 \\
\text { weeks }\end{array}$ & $\begin{array}{c}\text { Prevention of eGFR } \\
\text { worsening; limited impact } \\
\text { on HOMA-IR }\end{array}$ & $\begin{array}{l}\text { Fukuda et al., } \\
2015 \text { [81] }\end{array}$ \\
\hline Obesity & $\begin{array}{l}\text { Randomized, } \\
\text { placebo-controlled study }\end{array}$ & $\begin{array}{c}30 \text { patients with central } \\
\text { obesity }\end{array}$ & $\begin{array}{l}60 \mathrm{mg} / \text { day propolis, } \\
\text { orally for } 2 \text { weeks }\end{array}$ & Reduction of leptin level & $\begin{array}{l}\text { Natsir et al., } \\
2020 \text { [82] }\end{array}$ \\
\hline $\begin{array}{l}\text { Diabetic } \\
\text { foot ulcer }\end{array}$ & $\begin{array}{l}\text { Randomized controlled } \\
\text { study }\end{array}$ & $\begin{array}{l}31 \text { patients with diabetic } \\
\text { foot wounds }\end{array}$ & $\begin{array}{c}\text { Cutaneously applied } \\
\text { propolis }\end{array}$ & $\begin{array}{l}\text { Reduction of wound area, } \\
\text { accelerated healing; } \\
\text { reduced TNF } \alpha\end{array}$ & $\begin{array}{l}\text { Mujica et al., } \\
2019 \text { [83] }\end{array}$ \\
\hline $\begin{array}{l}\text { Diabetic } \\
\text { foot ulcer }\end{array}$ & $\begin{array}{c}\text { Prospective, controlled } \\
\text { study }\end{array}$ & $\begin{array}{l}24 \text { patients with diabetic } \\
\text { food ulcer }\end{array}$ & $\begin{array}{c}\text { Cutaneously applied } \\
\text { propolis }\end{array}$ & $\begin{array}{l}41 \% \text { reduction of ulcer } \\
\text { area; accelerated wound } \\
\text { healing }\end{array}$ & $\begin{array}{c}\text { Henshaw et al., } \\
2014 \text { [84] }\end{array}$ \\
\hline
\end{tabular}

In diabetic patients there is a significant risk of macrovascular or microvascular complications with a high mortality rate and impaired quality of life. Several randomized controlled studies (Afsharpour et al., 2019; Zakerkish et al., 2019; Samadi et al., 2017) proved that oral administration of propolis for at least 2 months in diabetic patients caused a reduction of fasting blood glucose (FBG) and glycosilated hemoglobin (HbA1C), which are 
considered important predictors of vascular complications, therefore showing a significant protective effect in diabetes mellitus [77-79]. However, other clinical studies (Zhao et al., 2016; Fukuda et al., 2015) did not show a significant influence on glucose level itself in diabetic patients treated with propolis but demonstrated a reduction of oxidative stress and inflammation, with favorable consequences in long-term management of diabetes mellitus $[80,81]$. The differences between clinical studies could be caused by multiple factors like variations of the doses used in patient treatment, a different geographical origin of propolis with a subsequently modified chemical composition or differences in study design and surveyed outcomes.

Only one clinical study (Natsir et al., 2020) evaluated the effect of propolis in a small cohort of patients with central obesity, proving a reduction of leptin level, without assessing other endpoints [82].

Additionally, the randomized controlled studies of Mujica et al., 2019 and Henshaw et al., 2014 demonstrated a significant effect of cutaneously applied propolis in the treatment of an important diabetic complication, the diabetic foot ulcer, the obtained results showing an accelerated wound healing in treated patients $[83,84]$.

The presented clinical studies have some limitations, being represented by small scale randomized placebo controlled trials (RCTs) using a reduced number of enrolled patients. Therefore, larger clinical trials with a superior statistical significance are needed in order to warrant a possible clinical use of propolis in diabetes mellitus, its complications, or other metabolic diseases.

\section{Mechanistic Studies with Active Constituents from Propolis in Metabolic Diseases}

\subsection{Inhibition of Alpha-Amylase and Alpha-Glucosidase in Diabetes Mellitus}

Alpha-amylase and alpha-glucosidase are digestive enzymes necessary for the breakdown of complex molecules like starch or maltose to glucose, which can be absorbed into the bloodstream and subsequently used as energy source. The most important of the two enzymes is alpha-glucosidase, situated on the brush border of the small intestine which is capable of hydrolyzing disaccharides to alpha-glucose. The inhibition of alpha-glucosidase can decrease the glucose absorption and finally the amount of glucose in the bloodstream [85].

Several drugs with inhibitory effects on alpha glucosidase can mitigate postprandial hyperglycemic peaks, being useful in the treatment of type 2 diabetes. However, multiple adverse effects like abdominal cramps or diarrhea could reduce patient adherence to treatment [85], therefore natural products with alpha glucosidase inhibitory effect may become successful drug candidates for the management of diabetes mellitus. The study of Pujirahayu et al., 2019 tested the inhibitory effect of several triterpenes from propolis (cycloartenol, ambonic acid, mangiferonic acid, and ambolic acid) on alpha-glucosidase. The results showed that mangiferonic acid from propolis had the strongest inhibitory effect on alpha-glucosidase with an IC50 of $3.46 \mu \mathrm{M} / \mathrm{mL}$ (Figure 1) [86].

\subsection{Modulation of Insulin Receptor Signaling in Diabetes Mellitus}

Insulin receptor signaling leading to the translocation of glucose transporters on the membrane of hepatocytes, adipocytes, and skeletal muscle cells is a key process involved in the regulation of glucose, lipid, and energy metabolism [87]. The modulation of insulin receptor signaling in different steps of the intracellular pathway can augment the response to insulin in several types of tissues and subsequently reduce insulin resistance [87].

Several insulin receptor signaling modulators of natural origin have been tested with promising results. The research of Liu et al., 2018 proved that two important chemical constituents from propolis, galangin, and pinocembrin modulated insulin receptor signaling acting via Akt/mTOR pathway. The two compounds reduced insulin resistance by upregulating IR, Akt, and GSK3 $\beta$ and downregulating the phosphorylation of IRS. It is known that in diabetes the serine/threonine phosphorylation of IRS may cause a reduction of insulin signal transduction, therefore the intracellular effect of galangin and 
pinocembrin from propolis can restore insulin receptor sensitivity and alleviate insulin resistance, as shown in Figure 1 [88].

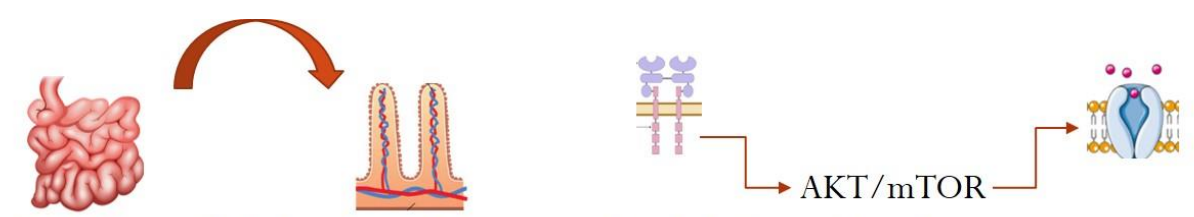

Inhibition of alpha-glucosidase Modulation of insulin receptor signaling

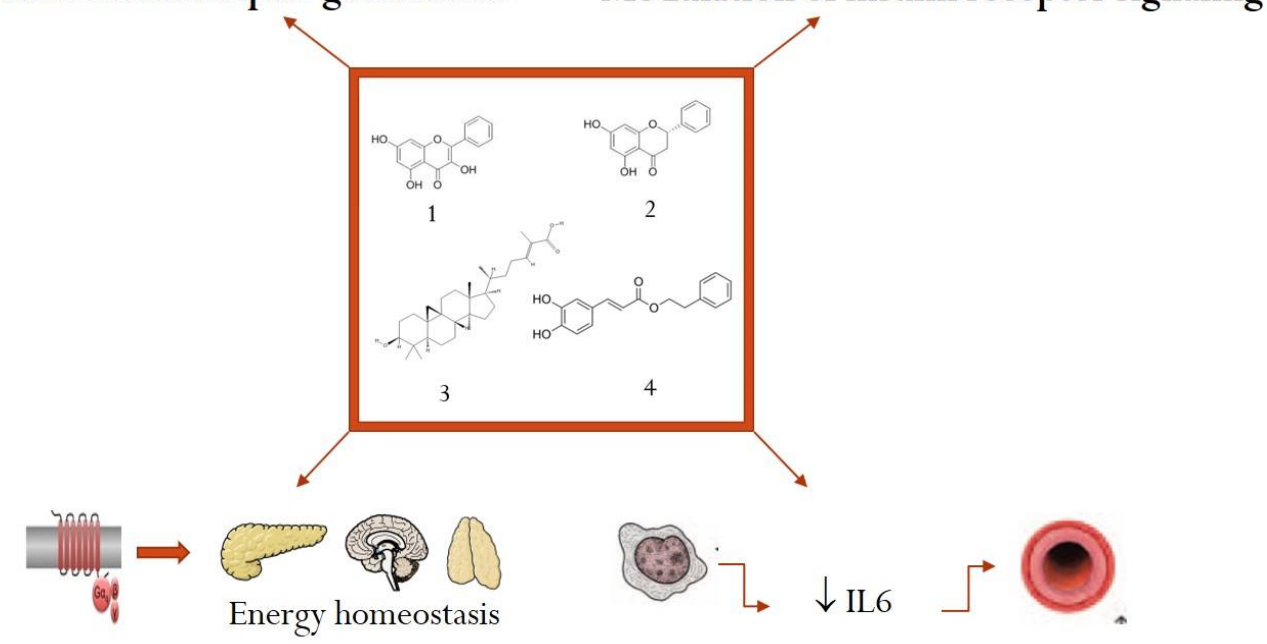

Activation of FFA4 receptor Reduction of IL-6 in atherosclerosis

Figure 1. Examples of mechanisms of action of selected active constituents from propolis in metabolic diseases (1-galangin, 2-pinocembrin, 3-mangiferonic acid, 4-CAPE).

Additionally, the study of Nie et al., 2017 showed that caffeic acid phenethyl ester (CAPE) present in the chemical composition of propolis was able to enhance p-Akt, inhibiting simultaneously $\mathrm{p}-\mathrm{JNK}$, amplifying insulin effects at receptor level with a reduction of insulin resistance in diabetic mice [89].

\subsection{Anti-Inflammatory Mechanisms in Dyslipidemia and Atherosclerosis}

Recently, atherosclerosis is increasingly regarded as an inflammatory condition at vascular level, an inhibition of inflammatory processes being considered a valuable strategy to reduce the progression of endothelial lesions. Hence, IL-6, a pro-inflammatory cytokine produced mainly by macrophages can favor the development and progression of atherosclerosis. In humans, a clinical trial (Bacchiega et al., 2017) proved that IL-6 is a major player in the inflammatory events leading to atherosclerosis and the blockade of this cytokine with specific inhibitors like tocilizumab may reduce cardiovascular risk, unfortunately with significant adverse reactions [90]. Other cytokines like IL-17 have inhibitory roles, the study of Simon et al. proving that elevated levels of IL-17 are associated with better outcomes in patients with myocardial infarction, due to atherosclerosis [91].

Propolis proved to be a significant inhibitor of IL-6 in experimental models of inflammation and, in addition, the study of Fang et al., 2013 proved that propolis decreased the level of IL- 6 while increasing IL-17 in a rodent model of dyslipidemia and atherosclerosis [71]. A previously published study of Bachiega et al., 2012 showed that cinnamic and coumaric acids from propolis significantly inhibited IL-6 production in macrophages from $\mathrm{BALB} / \mathrm{c}$ mice [92].

\subsection{Antioxidant Mechanisms in Dyslipidemia}

A series of in vitro and in vivo experimental models have shown that oxidative stress is directly involved in the pathogenesis of atherosclerosis, the life-threatening consequence 
of dyslipidemia. In the vascular wall, oxidized low density lipoproteins are internalized in macrophages with the formation of foam cells which promote cell proliferation and endothelial dysfunction. In hypercholesterolemic animals, atherosclerotic processes were favored by the generation of reactive oxygen species which induced an increased oxidation of LDL [72].

Propolis has a high content of antioxidant molecules, being able to decrease lipid peroxidation and the generation of reactive oxygen species with positive effects on the cardiovascular system. Silva et al., 2015 demonstrated that propolis was able to prevent left ventricular hypertrophy (LVH) and atherogenesis in hypercholesterolemic mice, due to its ability to eliminate superoxide and hydroxyl radicals and the reduction of CD40L expression [70].

The chemical constituents from propolis responsible for the antioxidant effect are considered to be polyphenols and flavonoids, present in all types of propolis in different concentrations, influenced by plant origin, bee species, temperature, or geographic factors. The study of Kocot et al., 2018 identified specific propolis compounds like 3,5dicaffeoylquinic acid, artepillin C or 3,4,5-tricaffeoylquinic acid as being responsible for the antioxidant effect [93].

\subsection{Activation of FFA4 Receptor with Positive Effects in Obesity}

Obesity is a complex and multifactorial disease, which can lead to an inflammatory condition triggered by the toll-like receptor 4 (TLR4), with a role in the etiology of cardiovascular diseases [94]. The inflammatory response from obesity can be mitigated by some unsaturated fatty acids like eicosapentaenoic acid (EPA) or docosahexaenoic acid (DHA), which are agonists on the free fatty acid receptor 4 (FFA4). This G-protein coupled receptor is present in the enteric nervous system but also in adipocytes, pancreas, or brain, being involved also in the regulation of energy homeostasis, appetite control, or adipocyte differentiation. The activation of FFA4 receptor leads to a reduction of the kinase activated by the growth factor beta (TAK1) activity and consequently an inhibition of IKK- $\beta / \mathrm{NF}-\mathrm{k} \beta$ and JNK/AP-1 pathway with anti-inflammatory consequences [94].

The study of Cho et al., 2020 found that several phenolic constituents from propolis like pinocembrin, chrysin, and galangin were able to activate the FFA4 receptor in vitro. Pinocembrin, a flavanonic compound from propolis, was the most potent activator of FFA4 receptor with potential applications in the pharmacological management of obesity and its complications [95].

\section{Safety Profile of Propolis}

Propolis is a natural product that is widely accepted by patients at a time when natural products are increasingly popular, to the detriment of chemically produced drugs. Although several in vivo studies in animals and humans aimed at demonstrating certain therapeutic effects of propolis were performed, they were not focused on the determination of adverse effects and toxicity, as propolis is generally recognized as safe (GRAS) [96]. Most of the chemical constituents in propolis are harmless and well tolerated if the doses are not too high. It is estimated that ingestion of $70 \mathrm{mg}$ propolis/day is potentially nontoxic for the organism, however, exceeding the dose of $15 \mathrm{~g} /$ day may cause adverse effects $[15,97]$. The major compounds in propolis belong to the class of polyphenols (flavonoids, phenolic acids, and their esters). It is considered that except for caffeic acid phenethyl ester (CAPE), all other polyphenols have a low order of acute oral toxicity, but the toxicity of individual compounds was rarely tested. A study showed that galangin, an important chemical constituent from propolis, had no toxicity in doses up to $320 \mathrm{mg} / \mathrm{kg}$ in Wistar rats [98]. Pinocembrin, another active constituent from propolis was found to be non-toxic and non-mutagenic in doses up to $100 \mathrm{mg} / \mathrm{kg}$ in rats [99].

In humans, the occurrence of adverse effects following the administration of propolis has been observed both in oral and in local administration to the skin or throat. As a direct result of topical application of cosmetic and pharmaceutical formulations, adverse 
reactions included dermatitis, urticaria, swelling, and ulcerative gingivitis, especially in atopic patients. The study of Walgrave et al., 2005, reported that $1.2-6.6 \%$ of dermatitis patients were sensitive to propolis [100]. In general, adverse reactions were moderate, but literature also mentioned cases of patients with anaphylactic shock with laryngeal edema induced by the local administration of propolis [101]. The studies aimed to assess the allergenic potential of propolis have revealed that the major allergen in propolis is LB-1, which is a mixture of three isomeric pentenyl caffeates $[15,101]$.

Despite the numerous studies focused on its chemical composition and beneficial effects, a chemical standardization of propolis is necessary, in order to be officially accepted into the mainstream of health care systems. However, due to its complex and variable chemical composition, it is difficult to find universally valid criteria. Literature mentions Bankova's approach, which considers that a quantification by group of structurally related compounds is more appropriate [102]. Future studies will continue the efforts to standardize propolis, for a safer and more effective administration.

\title{
8. Conclusions
}

Our review identified 22 preclinical and 8 clinical studies, which proved a series of favorable effects of propolis in diabetes mellitus, dyslipidemia, and obesity. Inhibition of alpha-glucosidase, modulation of insulin receptor signaling, reduction of IL-6, and activation of FFA4 receptors were the most important mechanisms of action identified for several chemical constituents from propolis: galangin, pinocembrin, mangiferonic acid, and CAPE. Additional studies are needed to ascertain the importance of propolis as a useful functional food for the prevention and treatment of metabolic diseases.

Author Contributions: Conceptualization, O.V., G.B. and C.S.; methodology, C.E.P.; software, A.C.; validation, C.M., I.I. and A.C.; formal analysis, C.M.; investigation, G.B., O.V. and C.S.; resources, C.E.P.; data curation, G.B.; writing—original draft preparation, O.V.; writing-review and editing, C.M., I.I. and A.C.; visualization, C.M.; supervision, C.E.P.; project administration, O.V.; funding acquisition, C.E.P. All authors have read and agreed to the published version of the manuscript.

Funding: This research received no external funding.

Institutional Review Board Statement: Not applicable.

Informed Consent Statement: Not applicable.

Data Availability Statement: Not applicable.

Conflicts of Interest: The authors declare no conflict of interest.

\author{
Abbreviations \\ ALT aspartate aminotransferase \\ APOE2 apolipoprotein E2 \\ FFA4 free fatty acid receptor 4 \\ FGF fibroblast growth factor \\ HDL high-density lipoprotein \\ HOMA-R homeostasis model assessment for insulin resistance \\ IC50 half-maximal inhibitory concentration \\ IRS insulin receptor substrate \\ LDL low-density lipoprotein \\ LVH left ventricular hypertrophy \\ MMP-9 matrix metalloproteinase 9 \\ mTOR mammalian target of rapamycin \\ PPAR peroxysome proliferator activated receptor \\ SREBP sterol regulatory element binding protein \\ STZ streptozotocin \\ VCAM vascular cell adhesion molecule-1 \\ VEGF vascular endothelial growth factor
}




\section{References}

1. Anjum, S.I.; Ullah, A.; Khan, K.A.; Attaullah, M.; Khan, H.; Ali, H.; Bashir, M.A.; Tahir, M.; Ansari, M.J.; Ghramh, H.A.; et al. Composition and functional properties of propolis (bee glue): A review. Saudi J. Biol. Sci. 2019, 26, 1695-1703. [CrossRef]

2. Bankova, V.S.; De Castro, S.L.; Marcucci, M.C. Propolis: Recent advances in chemistry and plant origin. Apidologie 2000, 31, 3-15. [CrossRef]

3. Galeotti, F.; Maccari, F.; Fachini, A.; Volpi, N. Chemical Composition and Antioxidant Activity of Propolis Prepared in Different Forms and in Different Solvents Useful for Finished Products. Foods 2018, 7, 41. [CrossRef]

4. Šturm, L.; Ulrih, N.P. Advances in the Propolis Chemical Composition between 2013 and 2018: A Review. eFood 2019, 1, 24. [CrossRef]

5. Pereira, R.L.R.; Salatino, M.L.F.; Salatino, A. Production of propolis and geopropolis by stingless bees. MOJ Food Process. Technol. 2020, 8, 1-3. [CrossRef]

6. Santos, L.M.; Da Fonseca, M.S.; Sokolonski, A.R.; Deegan, K.R.; Araújo, R.P.C.; Umsza-Guez, M.A.; Barbosa, J.D.V.; Portela, R.D.; Machado, B.A.S. Propolis: Types, composition, biological activities, and veterinary product patent prospecting. J. Sci. Food Agric. 2020, 100, 1369-1382. [CrossRef]

7. Castaldo, S.; Capasso, F. Propolis, an old remedy used in modern medicine. Fitoterapia 2002, 73, S1-S6. [CrossRef]

8. Huang, S.; Zhang, C.-P.; Wang, K.; Li, G.Q.; Hu, F.-L. Recent Advances in the Chemical Composition of Propolis. Molecules 2014, 19, 19610-19632. [CrossRef]

9. Bankova, V. Recent trends and important developments in propolis research. Evid. Based Complement. Altern. Med. 2005, 2, 29-32. [CrossRef]

10. Alday, M.N.-N.E. Advances in Pharmacological Activities and Chemical Composition of Propolis Produced in Americas. In Beekeeping and Bee Conservation-Advances in Research; IntechOpen: London, UK, 2016.

11. Talhouk, R.; Salloum, R.; Homaidan, F. Inflammatory Diseases. In Medicinal Plants; Apple Academic Press: Palm Bay, FL, USA, 2012; pp. 495-525.

12. Sforcin, J.M.; Bankova, V. Propolis: Is there a potential for the development of new drugs? J. Ethnopharmacol. 2011, 133, 253-260. [CrossRef]

13. Shahinozzaman, M.; Obanda, D.N.; Tawata, S. Chemical composition and pharmacological properties of Macaranga-Type Pacific propolis: A review. Phytother. Res. 2021, 35, 207-222. [CrossRef]

14. Derevici, A.; Popesco, A.; Popesco, N. Recherches sur Certaines Propriétés Biologiques de la Propolis. Apidologie 1964, 7, 191-200. [CrossRef]

15. Wagh, V.D. Propolis: A Wonder Bees Product and Its Pharmacological Potentials. Adv. Pharmacol. Sci. 2013, $2013,308249$. [CrossRef]

16. Sarıçoban, C.; Yerlikaya, S. As a Protective Material: Propolis. J. Agroaliment. Process. Technol. 2016, $22,56-63$.

17. Khalil, M.L. Biological activity of bee propolis in health and disease. Asian Pac. J. Cancer Prev. 2006, 7, $22-31$.

18. Sun, S.; He, J.; Liu, M.; Yin, G.; Zhang, X. A Great Concern Regarding the Authenticity Identification and Quality Control of Chinese Propolis and Brazilian Green Propolis. J. Food Nutr. Res. 2019, 7, 725-735. [CrossRef]

19. Alenezi, S.S.; Natto, M.J.; Igoli, J.O.; Gray, A.I.; Fearnley, J.; Fearnley, H.; De Koning, H.P.; Watson, D.G. Novel flavanones with anti-trypanosomal activity isolated from Zambian and Tanzanian propolis samples. Int. J. Parasitol. Drugs Drug Resist. 2020, 14, 201-207. [CrossRef] [PubMed]

20. Inui, S.; Hosoya, T.; Yoshizumi, K.; Sato, H.; Kumazawa, S. Phytochemical and anti-inflammatory properties of Senegalese propolis and isolated compounds. Fitoterapia 2021, 151, 104861. [CrossRef] [PubMed]

21. Mukaide, K.; Honda, S.; Vongsak, B.; Kumazawa, S. Prenylflavonoids from propolis collected in Chiang Mai, Thailand. Phytochem. Lett. 2021, 43, 88-93. [CrossRef]

22. Stojanović, S.; Najman, S.J.; Bogdanova-Popov, B.; Najman, S.S. Propolis: Chemical Composition, Biological and Pharmacological Activity-A Review. Acta Med. Median. 2020, 59, 108-113. [CrossRef]

23. Athikomkulchai, S.; Awale, S.; Ruangrungsi, N.; Ruchirawat, S.; Kadota, S. Chemical constituents of Thai propolis. Fitoterapia 2013, 88, 96-100. [CrossRef]

24. Fu, S.-H.; Yang, M.-H.; Wen, H.-M.; Chern, J.-C. Analysis of flavonoids in propolis by capillary electrophoresis. J. Food Drug Anal. 2005, 13, 4. [CrossRef]

25. de Mendonça, I.C.G.; Porto, I.C.C.D.M.; Nascimento, T.G.D.; De Souza, N.S.; Oliveira, J.M.D.S.; Arruda, R.E.D.S.; Mousinho, K.C.; dos Santos, A.F.; Basílio-Júnior, I.D.; Parolia, A.; et al. Brazilian red propolis: Phytochemical screening, antioxidant activity and effect against cancer cells. BMC Complement. Altern. Med. 2015, 15, 357. [CrossRef]

26. Hamasaka, T.; Kumazawa, S.; Fujimoto, T.; Nakayama, T. Antioxidant Activity and Constituents of Propolis Collected in Various Areas of Japan. Food Sci. Technol. Res. 2004, 10, 86-92. [CrossRef]

27. Kahramanoğlu, I.; Okatan, V.; Wan, C. Biochemical Composition of Propolis and Its Efficacy in Maintaining Postharvest Storability of Fresh Fruits and Vegetables. J. Food Qual. 2020, 2020, 8869624. [CrossRef]

28. Miguel, M.G. Chemical and biological properties of propolis from the western countries of the Mediterranean basin and Portugal. Int. J. Pharm. Pharm. Sci. 2013, 5, 403-409. 
29. Noureddine, H.; Hage-Sleiman, R.; Wehbi, B.; Fayyad-Kazan, H.; Hayar, S.; Traboulssi, M.; Alyamani, O.A.; Faour, W.H.; ElMakhour, Y. Chemical characterization and cytotoxic activity evaluation of Lebanese propolis. Biomed. Pharmacother. 2017, 95, 298-307. [CrossRef]

30. Frozza, C.O.D.S.; Garcia, C.S.C.; Gambato, G.; de Souza, M.D.O.; Salvador, M.; Moura, S.; Padilha, F.F.; Seixas, F.K.; Collares, T.; Borsuk, S.; et al. Chemical characterization, antioxidant and cytotoxic activities of Brazilian red propolis. Food Chem. Toxicol. 2013, 52, 137-142. [CrossRef] [PubMed]

31. Trusheva, B.; Popova, M.; Bankova, V.; Simova, S.; Marcucci, M.C.; Miorin, P.L.; Pasin, F.D.R.; Tsvetkova, I. Bioactive Constituents of Brazilian Red Propolis. Evid. Based Complement. Altern. Med. 2006, 3, 249-254. [CrossRef]

32. Zheng, Y.-Z.; Deng, G.; Liang, Q.; Chen, D.-F.; Guo, R.; Lai, R.-C. Antioxidant Activity of Quercetin and Its Glucosides from Propolis: A Theoretical Study. Sci. Rep. 2017, 7, 7543. [CrossRef]

33. Wali, A.F.; Mushtaq, A.; Rehman, M.U.; Akbar, S.; Masoodi, M.H. Bee Propolis (Bee's Glue): A Phytochemistry Review. J. Crit. Rev. 2017, 4, 9-13. [CrossRef]

34. Afrouzan, H.; Tahghighi, A.; Zakeri, S.; Es-Haghi, A. Chemical Composition and Antimicrobial Activities of Iranian Propolis. Iran. Biomed. J. 2017, 22, 50-65. [PubMed]

35. Al-Ani, I.; Zimmermann, S.; Reichling, J.; Wink, M. Antimicrobial Activities of European Propolis Collected from Various Geographic Origins Alone and in Combination with Antibiotics. Medicines 2018, 5, 2. [CrossRef]

36. Anđelković, B.; Vujisić, L.; Vučković, I.; Tešević, V.; Vajs, V.; Gođevac, D. Metabolomics study of Populus type propolis. J. Pharm. Biomed. Anal. 2017, 135, 217-226. [CrossRef]

37. Zabaiou, N.; Fouache, A.; Trousson, A.; Baron, S.; Zellagui, A.; Lahouel, M.; Lobaccaro, J.-M.A. Biological properties of propolis extracts: Something new from an ancient product. Chem. Phys. Lipids 2017, 207, 214-222. [CrossRef] [PubMed]

38. Szliszka, E.; Kucharska, A.Z.; Sokół-Łętowska, A.; Mertas, A.; Czuba, Z.P.; Król, W. Chemical Composition and Anti-Inflammatory Effect of Ethanolic Extract of Brazilian Green Propolis on Activated J774A.1 Macrophages. Evid. Based Complement. Altern. Med. 2013, 2013, 976415. [CrossRef]

39. Cuesta-Rubio, O.; Fernández, M.C.; Hernández, I.M.; Jaramillo, C.G.J.; González, V.H.; Porto, R.M.D.O.; Delange, D.M.; Fidalgo, L.M.; Piccinelli, A.L.; Campone, L.; et al. Chemical profile and anti-leishmanial activity of three Ecuadorian propolis samples from Quito, Guayaquil and Cotacachi regions. Fitoterapia 2017, 120, 177-183. [CrossRef]

40. Oliveira, A.; França, H.; Kuster, R.; Teixeira, L.; Rocha, L. Chemical composition and antibacterial activity of Brazilian propolis essential oil. J. Venom. Anim. Toxins Incl. Trop. Dis. 2010, 16, 121-130. [CrossRef]

41. Papachroni, D.; Graikou, K.; Kosalec, I.; Damianakos, H.; Ingram, V.; Chinou, I. Phytochemical Analysis and Biological Evaluation of Selected African Propolis Samples from Cameroon and Congo. Nat. Prod. Commun. 2015, 10, 67-70. [CrossRef]

42. Popova, M.P.; Graikou, K.; Chinou, I.; Bankova, V.S. GC-MS Profiling of Diterpene Compounds in Mediterranean Propolis from Greece. J. Agric. Food Chem. 2010, 58, 3167-3176. [CrossRef]

43. Rushdi, A.I.; Adgaba, N.; Bayaqoob, N.I.M.; Al-Khazim, A.; Simoneit, B.R.T.; El-Mubarak, A.H.; Al-Mutlaq, K.F. Characteristics and chemical compositions of propolis from Ethiopia. SpringerPlus 2014, 3, 253. [CrossRef]

44. Soltani, E.-K.; Cerezuela, R.; Charef, N.; Mezaache-Aichour, S.; Esteban, M.A.; Zerroug, M.M. Algerian propolis extracts: Chemical composition, bactericidal activity and in vitro effects on gilthead seabream innate immune responses. Fish Shellfish Immunol. 2017, 62, 57-67. [CrossRef]

45. Eroglu, N.; Akkus, S.; Yaman, M.; Asci, B.; Silici, S. Amino Acid and Vitamin Content of Propolis Collected by Native Caucasican Honeybees. J. Apic. Sci. 2016, 60, 101-110. [CrossRef]

46. Ahangari, Z.; Naseri, M.; Vatandoost, F. Propolis: Chemical Composition and Its Applications in Endodontics. Iran. Endod. J. 2018, 13, 285-292.

47. Cardinault, N.; Cayeux, M.-O.; Du Sert, P.P. La propolis: Origine, composition et propriétés. Phytothérapie 2012, 10, 298-304. [CrossRef]

48. Al Mărghitaş, L.; Dezmirean, D.S.; Bobiş, O. Important Developments in Romanian Propolis Research. Evid. Based Complement. Altern. Med. 2013, 2013, 159392. [CrossRef] [PubMed]

49. Ristivojević, P.; Trifković, J.; Andrić, F.; Milojković-Opsenica, D. Poplar-type Propolis: Chemical Composition, Botanical Origin and Biological Activity. Nat. Prod. Commun. 2015, 10, 1869-1876. [CrossRef] [PubMed]

50. Saftić, L.; Peršurić, Ž.; Fornal, E.; Pavlešić, T.; Pavelić, S.K. Targeted and untargeted LC-MS polyphenolic profiling and chemometric analysis of propolis from different regions of Croatia. J. Pharm. Biomed. Anal. 2019, 165, 162-172. [CrossRef]

51. Andrade, J.K.S.; Denadai, M.; de Oliveira, C.S.; Nunes, M.L.; Narain, N. Evaluation of bioactive compounds potential and antioxidant activity of brown, green and red propolis from Brazilian northeast region. Food Res. Int. 2017, 101, 129-138. [CrossRef]

52. Toreti, V.C.; Sato, H.H.; Pastore, G.M.; Park, Y.K. Recent Progress of Propolis for Its Biological and Chemical Compositions and Its Botanical Origin. Evid. Based Complement. Altern. Med. 2013, 2013, 697390. [CrossRef]

53. Kumazawa, S.; Goto, H.; Hamasaka, T.; Fukumoto, S.; Fujimoto, T.; Nakayama, T. A New Prenylated Flavonoid from Propolis Collected in Okinawa, Japan. Biosci. Biotechnol. Biochem. 2004, 68, 260-262. [CrossRef]

54. Devequi-Nunes, D.; Machado, B.A.S.; Barreto, G.D.A.; Silva, J.R.; Da Silva, D.F.; Da Rocha, J.L.C.; Brandão, H.N.; Borges, V.M.; Umsza-Guez, M.A. Chemical characterization and biological activity of six different extracts of propolis through conventional methods and supercritical extraction. PLoS ONE 2018, 13, e0207676. [CrossRef] 
55. Laaroussi, H.; Bakour, M.; Ousaaid, D.; Aboulghazi, A.; Ferreira-Santos, P.; Genisheva, Z.; Teixeira, J.A.; Lyoussi, B. Effect of antioxidant-rich propolis and bee pollen extracts against D-glucose induced type 2 diabetes in rats. Food Res. Int. 2020, 138, 109802. [CrossRef]

56. Nna, V.U.; Abu Bakar, A.B.; Ahmad, A.; Eleazu, C.O.; Mohamed, M. Oxidative Stress, NF-кB-Mediated Inflammation and Apoptosis in the Testes of Streptozotocin-Induced Diabetic Rats: Combined Protective Effects of Malaysian Propolis and Metformin. Antioxidants 2019, 8, 465. [CrossRef] [PubMed]

57. El Menyiy, N.; Al-Wali, N.; El Ghouizi, A.; El-Guendouz, S.; Salom, K.; Lyoussi, B. Potential therapeutic effect of Moroccan propolis in hyperglycemia, dyslipidemia, and hepatorenal dysfunction in diabetic rats. Iran. J. Basic Med. Sci. 2019, 22, 1331-1339.

58. Rivera-Yañez, N.; Rodriguez-Canales, M.; Nieto-Yañez, O.; Jiménez-Estrada, M.; Ibarra-Barajas, M.; Canales-Martinez, M.M.; Rodriguez-Monroy, M.A. Hypoglycaemic and Antioxidant Effects of Propolis of Chihuahua in a Model of Experimental Diabetes. Evid. Based Complement. Altern. Med. 2018, 2018, 4360356. [CrossRef] [PubMed]

59. Vongsak, B.; Kongkiatpaiboon, S.; Jaisamut, S.; Machana, S.; Pattarapanich, C. In vitro alpha glucosidase inhibition and freeradical scavenging activity of propolis from Thai stingless bees in mangosteen orchard. Rev. Bras. Farmacogn. 2015, 25, 445-450. [CrossRef]

60. Popova, M.; Lyoussi, B.; Aazza, S.; Antunes, D.; Bankova, V.; Miguel, G. Antioxidant and $\alpha$-Glucosidase Inhibitory Properties and Chemical Profiles of Moroccan Propolis. Nat. Prod. Commun. 2015, 10, 1961-1964. [CrossRef]

61. Ibrahim, R.B.; Amin, A.; Mustafa, I.O.; Onanuga, I.O.; Folarin, R.O.; Balogun, W.G. Hepatoprotective and Pancreatoprotective Properties of the Ethanolic Extract of Nigerian Propolis. J. Intercult. Ethnopharmacol. 2015, 4, 102-108. [CrossRef]

62. Zhu, W.; Chen, M.; Shou, Q.; Li, Y.; Hu, F. Biological Activities of Chinese Propolis and Brazilian Propolis on StreptozotocinInduced Type 1 Diabetes Mellitus in Rats. Evid. Based Complement. Altern. Med. 2011, 2011, 468529. [CrossRef]

63. El-Sayed, E.-S.M.; Abo-Salem, O.M.; Aly, H.A.; Mansour, A.M. Potential antidiabetic and hypolipidemic effects of propolis extract in streptozotocin-induced diabetic rats. Pak. J. Pharm. Sci. 2009, 22, 168-174.

64. Zamami, Y.; Takatori, S.; Koyama, T.; Goda, M.; Iwatani, Y.; Doi, S.; Kawasaki, H. Effect of propolis on insulin resistance in fructose-drinking rats. J. Pharm. Soc. Jpn. 2007, 127, 2065-2073. [CrossRef]

65. Fuliang, H.; Hepburn, H.; Xuan, H.; Chen, M.; Daya, S.; Radloff, S. Effects of propolis on blood glucose, blood lipid and free radicals in rats with diabetes mellitus. Pharmacol. Res. 2005, 51, 147-152. [CrossRef]

66. Matsui, T.; Ebuchi, S.; Fujise, T.; Abesundara, K.J.M.; Doi, S.; Yamada, H.; Matsumoto, K. Strong Antihyperglycemic Effects of Water-Soluble Fraction of Brazilian Propolis and Its Bioactive Constituent, 3,4,5-Tri-O-caffeoylquinic Acid. Biol. Pharm. Bull. 2004, 27, 1797-1803. [CrossRef] [PubMed]

67. Oršolić, N.; Jurčević, I.L.; Đikić, D.; Rogić, D.; Odeh, D.; Balta, V.; Junaković, E.P.; Terzić, S.; Jutrić, D. Effect of Propolis on Diet-Induced Hyperlipidemia and Atherogenic Indices in Mice. Antioxidants 2019, 8, 156. [CrossRef]

68. Azab, A.E.; Lashkham, N.M.; Albasha, M.O. Haemato-Protective and Hypolipidemic Effects of Aqueous Extract of Libyan Propolis Against Sodium Nitrite Induced Haematotoxicity and Hyperlipidemia in Guinea Pigs. Am. J. Biosci. Bioeng. 2015, 3, 22-32. [CrossRef]

69. Albokhadaim, I. Influence of dietary supplementation of propolis on hematology, biochemistry and lipid profile of rats fed high cholesterol diet. J. Adv. Vet. Anim. Res. 2015, 2, 56-63. [CrossRef]

70. Silva, D.; Miranda, A.; D’Angelo, L.R.B.; Rosa, B.; Soares, E.; Ramalho, J.G.D.C.; Boriollo, M.F.G.; Garcia, J.A.D. Propolis and swimming in the prevention of atherogenesis and left ventricular hypertrophy in hypercholesterolemic mice. Braz. J. Biol. 2015, 75, 414-422. [CrossRef]

71. Fang, Y.; Sang, H.; Yuan, N.; Sun, H.; Yao, S.; Wang, J.; Qin, S. Ethanolic extract of propolis inhibits atherosclerosis in ApoEknockout mice. Lipids Heath. Dis. 2013, 12, 123. [CrossRef]

72. Daleprane, J.B.; Freitas, V.D.S.; Pacheco, A.; Rudnicki, M.; Faine, L.A.; Dörr, F.A.; Ikegaki, M.; Salazar, L.A.; Ong, T.P.; Abdalla, D.S.P. Anti-atherogenic and anti-angiogenic activities of polyphenols from propolis. J. Nutr. Biochem. 2012, 23, 557-566. [CrossRef]

73. Nader, M.A.; El-Agamy, D.S.; Suddek, G.M. Protective effects of propolis and thymoquinone on development of atherosclerosis in cholesterol-fed rabbits. Arch. Pharmacal Res. 2010, 33, 637-643. [CrossRef]

74. Ichi, I.; Hori, H.; Takashima, Y.; Adachi, N.; Kataoka, R.; Okihara, K.; Hashimoto, K.; Kojo, S. The Beneficial Effect of Propolis on Fat Accumulation and Lipid Metabolism in Rats Fed a High-Fat Diet. J. Food Sci. 2009, 74, H127-H131. [CrossRef] [PubMed]

75. Nishikawa, S.; Hyodo, T.; Aoyama, H.; Miyata, R.; Kumazawa, S.; Tsuda, T. Artepillin C, a Key Component of Brazilian Propolis, Induces Thermogenesis in Inguinal White Adipose Tissue of Mice through a Creatine-Metabolism-Related Thermogenic Pathway. J. Agric. Food Chem. 2019, 68, 1007-1014. [CrossRef] [PubMed]

76. Koya-Miyata, S.; Arai, N.; Mizote, A.; Taniguchi, Y.; Ushio, S.; Iwaki, K.; Fukuda, S. Propolis Prevents Diet-Induced Hyperlipidemia and Mitigates Weight Gain in Diet-Induced Obesity in Mice. Biol. Pharm. Bull. 2009, 32, 2022-2028. [CrossRef] [PubMed]

77. Afsharpour, F.; Javadi, M.; Hashemipour, S.; Koushan, Y.; Haghighian, H.K. Propolis supplementation improves glycemic and antioxidant status in patients with type 2 diabetes: A randomized, double-blind, placebo-controlled study. Complement. Ther. Med. 2019, 43, 283-288. [CrossRef]

78. Zakerkish, M.; Jenabi, M.; Zaeemzadeh, N.; Hemmati, A.A.; Neisi, N. The Effect of Iranian Propolis on Glucose Metabolism, Lipid Profile, Insulin Resistance, Renal Function and Inflammatory Biomarkers in Patients with Type 2 Diabetes Mellitus: A Randomized Double-Blind Clinical Trial. Sci. Rep. 2019, 9, 7289. [CrossRef] 
79. Samadi, N.; Mozaffari-Khosravi, H.; Rahmanian, M.; Askarishahi, M. Effects of bee propolis supplementation on glycemic control, lipid profile and insulin resistance indices in patients with type 2 diabetes: A randomized, double-blind clinical trial. J. Integr. Med. 2017, 15, 124-134. [CrossRef]

80. Zhao, L.; Pu, L.; Wei, J.; Li, J.; Wu, J.; Xin, Z.; Gao, W.; Guo, C. Brazilian Green Propolis Improves Antioxidant Function in Patients with Type 2 Diabetes Mellitus. Int. J. Environ. Res. Public Health 2016, 13, 498. [CrossRef]

81. Fukuda, T.; Fukui, M.; Tanaka, M.; Senmaru, T.; Iwase, H.; Yamazaki, M.; Aoi, W.; Inui, T.; Nakamura, N.; Marunaka, Y. Effect of Brazilian green propolis in patients with type 2 diabetes: A double-blind randomized placebo-controlled study. Biomed. Rep. 2015, 3, 355-360. [CrossRef]

82. Natsir, R.; Usman, A.N.; Ardyansyah, B.D.; Fendi, F. Propolis and honey trigona decrease leptin levels of central obesity patients. Enfermería Clínica 2020, 30, 96-99. [CrossRef]

83. Mujica, V.; Orrego, R.; Fuentealba, R.; Leiva, E.; Zúñiga-Hernández, J. Propolis as an Adjuvant in the Healing of Human Diabetic Foot Wounds Receiving Care in the Diagnostic and Treatment Centre from the Regional Hospital of Talca. J. Diabetes Res. 2019, 2019, 2507578. [CrossRef] [PubMed]

84. Henshaw, F.R.; Bolton, T.; Nube, V.; Hood, A.; Veldhoen, D.; Pfrunder, L.; McKew, G.L.; Macleod, C.; McLennan, S.V.; Twigg, S.M. Topical application of the bee hive protectant propolis is well tolerated and improves human diabetic foot ulcer healing in a prospective feasibility study. J. Diabetes Complicat. 2014, 28, 850-857. [CrossRef] [PubMed]

85. Chiba, S. Molecular Mechanism in $\alpha$-Glucosidase and Glucoamylase. Biosci. Biotechnol. Biochem. 1997, 61, 1233-1239. [CrossRef] [PubMed]

86. Pujirahayu, N.; Bhattacharjya, D.K.; Suzuki, T.; Katayama, T. $\alpha$-Glucosidase Inhibitory Activity of Cycloartane-Type Triterpenes Isolated from Indonesian Stingless Bee Propolis and Their Structure-Activity Relationship. Pharmaceuticals 2019, $12,102$. [CrossRef] [PubMed]

87. Boucher, J.; Kleinridders, A.; Kahn, C.R. Insulin Receptor Signaling in Normal and Insulin-Resistant States. Cold Spring Harb. Perspect. Biol. 2014, 6, a009191. [CrossRef]

88. Liu, Y.; Liang, X.; Zhang, G.; Kong, L.; Peng, W.; Zhang, H. Galangin and Pinocembrin from Propolis Ameliorate Insulin Resistance in HepG2 Cells via Regulating Akt/mTOR Signaling. Evid. Based Complement. Altern. Med. 2018, 2018, 7971842. [CrossRef] [PubMed]

89. Nie, J.; Chang, Y.; Li, Y.; Zhou, Y.; Qin, J.; Sun, Z.; Li, H. Caffeic Acid Phenethyl Ester (Propolis Extract) Ameliorates Insulin Resistance by Inhibiting JNK and NF-kB Inflammatory Pathways in Diabetic Mice and HepG2 Cell Models. J. Agric. Food Chem. 2017, 65, 9041-9053. [CrossRef]

90. Bacchiega, B.C.; Bacchiega, A.B.; Usnayo, M.J.G.; Bedirian, R.; Singh, G.; Pinheiro, G.D.R.C. Interleukin 6 Inhibition and Coronary Artery Disease in a High-Risk Population: A Prospective Community-Based Clinical Study. J. Am. Heart Assoc. 2017, 6, e005038. [CrossRef]

91. Simon, T.; Taleb, S.; Danchin, N.; Laurans, L.; Rousseau, B.; Cattan, S.; Montely, J.-M.; Dubourg, O.; Tedgui, A.; Kotti, S.; et al. Circulating levels of interleukin-17 and cardiovascular outcomes in patients with acute myocardial infarction. Eur. Heart J. 2012, 34, 570-577. [CrossRef]

92. Bachiega, T.F.; Orsatti, C.L.; Pagliarone, A.C.; Sforcin, J.M. The Effects of Propolis and its Isolated Compounds on Cytokine Production by Murine Macrophages. Phytother. Res. 2012, 26, 1308-1313. [CrossRef]

93. Kocot, J.; Kiełczykowska, M.; Luchowska-Kocot, D.; Kurzepa, J.; Musik, I. Antioxidant Potential of Propolis, Bee Pollen, and Royal Jelly: Possible Medical Application. Oxidative Med. Cell. Longev. 2018, 2018, 7074209. [CrossRef]

94. Rogero, M.M.; Calder, P.C. Obesity, Inflammation, Toll-Like Receptor 4 and Fatty Acids. Nutrients 2018, 10, 432. [CrossRef]

95. Cho, H.; Kim, K.; Kim, N.; Woo, M.; Kim, H.Y. Effect of propolis phenolic compounds on free fatty acid receptor 4 activation. Food Sci. Biotechnol. 2020, 29, 579-584. [CrossRef] [PubMed]

96. Siheri, W.; Alenezi, S.; Tusiimire, J.; Watson, D.G. The Chemical and Biological Properties of Propolis. In Bee Products-Chemical and Biological Properties; J.B. Metzler: Stuttgart, Germany, 2017; pp. 137-178.

97. Silva-Carvalho, R.; Baltazar, F.; Almeida-Aguiar, C. Propolis: A Complex Natural Product with a Plethora of Biological Activities That Can Be Explored for Drug Development. Evid. Based Complement. Altern. Med. 2015, 2015, 206439. [CrossRef] [PubMed]

98. Aloud, A.A.; Chinnadurai, V.; Govindasamy, C.; AlSaif, M.A.; Al-Numair, K.S. Galangin, a dietary flavonoid, ameliorates hyperglycaemia and lipid abnormalities in rats with streptozotocin-induced hyperglycaemia. Pharm. Biol. 2018, 56, 302-308. [CrossRef]

99. Charoensin, S.; Punvittayagul, C.; Pompimom, W.; Mevatee, U.; Wongpoomchai, R. Toxicological and clastogenic evaluation of pinocembrin and pinostrobin isolated from Boesenbergia pandurate in Wistar rats. Thai J. Toxicol. 2010, $25,29$.

100. Walgrave, S.E.; Warshaw, E.M.; Glesne, L.A. Allergic contact dermatitis from propolis. Dermatitis 2005, 16, 209-215.

101. Hsu, C.-Y.; Chiang, W.-C.; Weng, T.-I.; Chen, W.-J.; Yuan, A. Laryngeal edema and anaphalactic shock after topical propolis use for acute pharyngitis. Am. J. Emerg. Med. 2004, 22, 432-433. [CrossRef] [PubMed]

102. Bankova, V. Chemical diversity of propolis and the problem of standardization. J. Ethnopharmacol. 2005, 100, 114-117. [CrossRef] 